\title{
Tumor necrosis factor-a -308 G/A polymorphism and risk of sepsis, septic shock, and mortality: an updated meta-analysis
}

\author{
Hao Wang ${ }^{1, *}$, Shujin Guo ${ }^{2, *}$, Chun Wan ${ }^{1, *}$, Ting Yang ${ }^{1}$, Ni Zeng ${ }^{1}$, Yanqiu Wu ${ }^{1}$, Lei \\ Chen ${ }^{1}$, Yongchun Shen ${ }^{1}$ and Fuqiang Wen ${ }^{1}$ \\ ${ }^{1}$ Department of Respiratory and Critical Care Medicine, West China Hospital of Sichuan University and Division of Pulmonary \\ Diseases, State Key Laboratory of Biotherapy of China, Chengdu 610041, China \\ ${ }^{2}$ Internal Medicine of Sichuan Provincial People's Hospital and Sichuan Academy of Medical Science, Chengdu 610072, China \\ *These authors contributed equally to this work
}

Correspondence to: Yongchun Shen, email: shen_yongchun@126.com

Fuqiang Wen, email: wenfuqiang.scu@gmail.com

Keywords: sepsis, mortality, polymorphism, meta-analysis

Received: June 28, 2017

Accepted: August 27, 2017

Published: September 13, 2017

Copyright: Wang et al. This is an open-access article distributed under the terms of the Creative Commons Attribution License 3.0 (CC BY 3.0), which permits unrestricted use, distribution, and reproduction in any medium, provided the original author and source are credited.

\section{ABSTRACT}

Background: The -308G/A polymorphism in the gene encoding tumor necrosis factor-a (TNF-a) has been implicated in sepsis risk in many studies but with variable results. This study aimed to comprehensively assess the evidence of association between this polymorphism and risk of sepsis and sepsis-related mortality.

Materials and Methods: PubMed, EMBASE and other databases were searched to identify relevant studies, and data were analyzed using Review Manager 5.0 and STATA 12.0 .

Results: Data from 34 publications involving 12,284 subjects were metaanalyzed. Combined analysis revealed an association between TNF-a -308G/A gene polymorphism and risk of sepsis (AA+GA vs. GG, OR 1.35, 95\% CI 1.10-1.67, $P=0.005$ ). This association was observed in the Caucasian subgroup (OR 1.50, 95\% CI 1.13-2.00, $P=0.006$ ), but not in the Asian subgroup. Across the entire study population, the polymorphism was also significantly related to septic shock risk (OR $1.52,95 \%$ CI 1.18-1.95, $P=0.001$ ) but not to sepsis-related mortality (OR 0.99, 95\% CI 0.71-1.40, $P=0.97$ ).

Conclusions: This meta-analysis suggests that the -308G/A gene polymorphism in the TNF-a gene may contribute to risk of sepsis and septic shock, but not risk of mortality.

\section{INTRODUCTION}

Sepsis, which is usually caused by infection and mediated by severe systemic inflammation, creates a heavy disease burden worldwide. It is more likely than any other infectious disease to impair quality of life and ability to work. Despite extensive progress in sepsis management in recent decades, sepsis-related mortality remains as high as $30-50 \%$ [1]. This may reflect the lack of specific therapeutic strategies, which has inspired a growing literature aimed at investigating the pathogenesis of sepsis in order to explore unique therapeutic targets.

Growing evidence indicates that inflammatory cytokines play vital roles in regulating the host immune response and amplifying inflammation in sepsis. Single- nucleotide polymorphisms (SNPs) in the genes encoding these cytokines may be related to the risk of sepsis, and may even play roles in its pathogenesis [2, 3]. Among these diverse cytokines, tumor necrosis factor- $\alpha$ (TNF- $\alpha$ ) has attracted considerable attention. TNF- $\alpha$ is an intensively studied pro-inflammatory cytokine released mainly by activated neutrophils and macrophages that helps regulate the mammalian immune response and cellular homeostasis [4]. It stimulates various immune and structural cells, triggering release of large amounts of inflammatory mediators, which amplify the inflammatory response and cause severe systemic inflammation, eventually leading to sepsis [5].

Numerous studies have examined various SNPs in the TNF- $\alpha$ gene and their potential relationship to sepsis risk. In particular, several studies of the $-308 \mathrm{G} / \mathrm{A}$ 
polymorphism have suggested a relationship, but others have given contrasting results [6-9]. A systematic review in 2010 concluded that this polymorphism is associated with risk of sepsis, but not risk of sepsis-related mortality [10]. Because several studies on this potential association have been published since that review, we wanted to perform an updated meta-analysis in order to gain a comprehensive understanding of all available evidence through the end of 2016, including the studies analyzed in the 2010 review. We examined the potential associations of this polymorphism with risk of sepsis, septic shock and sepsis-related mortality.

\section{RESULTS}

\section{Characteristics of included publications and studies}

After systematic search of the literature and study selection, 34 publications (37 studies) involving 12,284 subjects from 16 countries were included in the metaanalysis (Table 1 and Supplementary Figure 1) [11-44]. These studies were published between 1999 and 2015. Fourteen studies were performed in Caucasians [22, 25 26, 28-30, 32-34, 36-37, 40-41, 43], 12 in Asians [11, 13-16, 19-20, 24, 31, 38-39, 44], and the remainder in populations of mixed or unknown ethnicity [12, 17-18, $21,23,27,35,42]$. In contrast, the most recent systematic review and meta-analysis of associations between the $-308 \mathrm{G} / \mathrm{A}$ polymorphism and sepsis contained 25 studies involving 2,977 patients [10]. Studies incorporated since that last review are marked with an asterisk in Table 1.

Of the 34 publications, 30 (33 studies) examined correlations between the TNF- $\alpha-308 \mathrm{~A} / \mathrm{G}$ polymorphism and risk of sepsis [11, 14-25, 27-40, 42-44], 8 examined correlations between this polymorphism and risk of septic shock [16, 22, 28, 35-36, 38-39, 43], and 16 examined correlations between this polymorphism and risk of sepsis-related mortality [12-13, 18-19, 22, 26, 28, 30-32, 34-36, 41-43]. Genotype distributions in case and control groups are shown in Supplementary Table 1. Distributions in control groups met the criteria of Hardy-Weinberg equilibrium (HWE) in 24 publications (71\%).

Study quality is assessed in Supplementary Table 2. Most publications (26 of 34, 76\%) provided detailed information about genotyping primers, and 32 publications reported the definition of sepsis, usually based on the definitions recommended by the American College of Chest Physicians/Society of Critical Care Medicine or by the International Sepsis Definitions Conferences [45-46]. On the other hand, fewer than one-third of publications (10 of $34,29 \%$ ) reported procedures for blinding.

\section{TNF- $\alpha-308 \mathrm{~A} / \mathrm{G}$ polymorphism and sepsis risk}

A total of 33 studies involving 11,590 subjects evaluated relationships between the TNF- $\alpha-308 \mathrm{~A} / \mathrm{G}$ polymorphism and overall risk of sepsis, which included sepsis, severe sepsis, and septic shock. The dominant model (AA+GA vs. GG) indicated a significant association between the TNF- $\alpha-308 \mathrm{~A} / \mathrm{G}$ polymorphism and sepsis risk (OR 1.35, 95\% CI 1.10-1.67, $P=0.005$; Figure 1). However, meta-analysis of only the 23 studies meeting HWE criteria showed no such association based on the dominant model (OR 1.28, 95\% CI 0.99-1.64, $P=0.06$ ).

Applying the dominant model to the subgroup of Caucasian subjects revealed a significant association between the polymorphism and sepsis risk (OR 1.50, 95\%CI 1.13-2.00, $P=0.006$; Figure 2). However, this association was not observed in the subgroup of Asian subjects (OR 1.56, 95\% CI 0.97-2.51, $P=0.07$ ). Results of meta-analyses assessing relationships between the $-308 \mathrm{~A} / \mathrm{G}$ polymorphism and overall risk of sepsis are summarized in Table 2.

\section{TNF- $\alpha-308 \mathrm{~A} / \mathrm{G}$ polymorphism and septic shock risk}

Eight studies involving 1,480 subjects examined association of the TNF- $\alpha-308 \mathrm{~A} / \mathrm{G}$ polymorphism with septic shock risk. Meta-analysis revealed a significant association based on the dominant model (OR 1.52, 95\% CI 1.18-1.95, $P=0.001$; Figure 3).

\section{TNF- $\alpha-308$ A/G polymorphism and sepsis- related mortality}

A total of 16 studies involving 2,850 patients with sepsis, of whom 2,064 survived through the end of the study and 786 did not, examined the potential relationship between the TNF- $\alpha-308 \mathrm{~A} / \mathrm{G}$ polymorphism and sepsisrelated mortality. None of the four statistical models revealed significant differences in genotype frequencies at the TNF- $\alpha-308 \mathrm{~A} / \mathrm{G}$ polymorphism between survivors and non-survivors (Table 2). Similar results were obtained for Caucasian and Asian subgroups (data not shown).

\section{Analysis of sensitivity and publication bias}

To assess the robustness of our meta-analysis results, we sequentially excluded each study from the complete set of 33 examining sepsis risk, and then we recalculated ORs. In each case, the results were similar to those obtained with the complete set of studies (Figure 4). Begg's funnel plot showed a symmetrical pattern for the dominant genetic model (AA+GA vs. GG) (Figure 5), and Egger's test gave a $P$ value of 0.63 , suggesting a lack of publication bias.

\section{DISCUSSION}

Our meta-analysis of the most complete and up-to-date set of studies published so far on potential 
relationships between the TNF- $\alpha-308 \mathrm{~A} / \mathrm{G}$ polymorphism and sepsis suggests that this polymorphism significantly contributes to the risk of sepsis and septic shock, but not to risk of sepsis-related mortality. Thus, this polymorphism appears to be a risk factor for sepsis, but not a mortality predictor.

TNF- $\alpha$, one of the most studied pro-inflammatory cytokines implicated in diverse diseases, is known to contribute to sepsis. The $-308 \mathrm{~A} / \mathrm{G}$ polymorphism in the TNF- $\alpha$ gene has been shown to up-regulate the gene's transcription [47], ultimately leading to higher levels of expressed protein in serum $[15-16,19]$. Elevated TNF- $\alpha$ levels enhance the inflammatory response and lead to the multiple phenotypic and functional characteristics of sepsis; they also induce apoptosis and reduce immune responsiveness and cell function [48-49].

An association between the $-308 \quad \mathrm{~A} / \mathrm{G}$ polymorphism and sepsis risk was observed in the entire study population, as well as in the subgroup of Caucasian participants. However, this association was not observed in the subgroup of Asian participants. This may reflect different prevalence of the SNPs in different ethnic groups. It may also mean that genetic risk factors for sepsis differ across ethnic groups. Further research should examine the possibility of ethnic bias in the associations of sepsis risk with certain alleles/genotypes at the $-308 \mathrm{~A} / \mathrm{G}$ polymorphism in the TNF- $\alpha$ gene, with certain alleles/ genotypes at other SNPs in the TNF- $\alpha$ gene, and with SNPs in other genes.

A subtype of sepsis is septic shock, which involves circulatory, cellular, and metabolic abnormalities. Septic shock is associated with higher risk of mortality than sepsis alone [50]. Our meta-analysis indicated a stronger association of the TNF- $\alpha-308 \mathrm{~A} / \mathrm{G}$ polymorphism with risk of septic shock (OR 1.52, 95\% CI 1.18-1.95) than with risk of sepsis (OR 1.35, 95\% CI 1.10-1.67). However, the meta-analysis did not indicate a significant association between the polymorphism and sepsis-related mortality (OR 0.99, 95\% CI 0.71-1.40). One possible explanation for the lack of association with mortality is that the SNPs in the TNF- $\alpha$ gene that influence protein expression differ between ethnic groups or even between individuals. Another explanation is environmental differences that may influence TNF- $\alpha$ transcription. It is

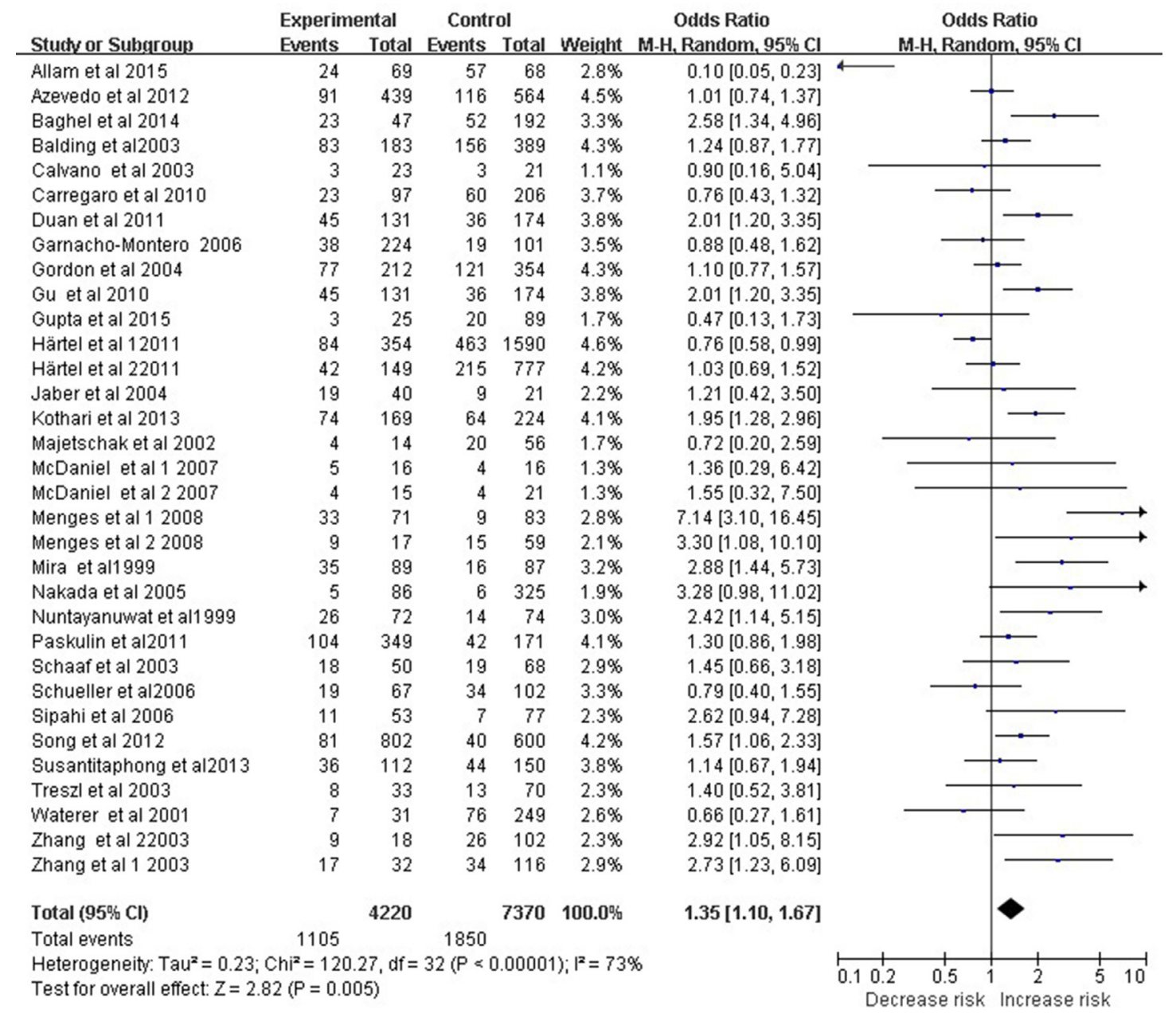

Figure 1: Meta-analysis to evaluate the association between the TNF- $\alpha-308$ A/G polymorphism and sepsis risk (AA+GA vs. GG). The size of the square is proportional to the weight of each study; horizontal lines represent the $95 \%$ CI. 


\begin{tabular}{|c|c|c|c|c|c|c|c|c|c|c|}
\hline Author/Year & Country & Ethnicity & Age group & Patient group & Sepsis type & Subjects & SNP method & $\begin{array}{c}\text { Sepsis risk } \\
\text { reported }\end{array}$ & $\begin{array}{c}\text { Septic } \\
\text { shock } \\
\text { risk } \\
\text { reported }\end{array}$ & $\begin{array}{l}\text { Mortality } \\
\text { reported }\end{array}$ \\
\hline Allam et al. $2015^{*}$ & Saudi Arabia & Asian & Neonate & NICU & $\mathrm{S}$ & 137 & Taqman & $\mathrm{Y}$ & $\mathrm{N}$ & $\mathrm{N}$ \\
\hline Cardoso et al. $2015^{*}$ & Brazil & Mixed & $\geq 18$ & $\mathrm{ICU}$ & $\mathrm{S}, \mathrm{SS}, \mathrm{SSH}$ & 72 & Taqman & $\mathrm{N}$ & $\mathrm{N}$ & $\mathrm{Y}$ \\
\hline Feng et al. $2015^{*}$ & China & Asian & NA & Pneumonia & SS, SSH & 277 & Taqman & $\mathrm{N}$ & $\mathrm{N}$ & $\mathrm{Y}$ \\
\hline Gupta et al. $2015^{*}$ & India & Asian & $\geq 16$ & Trauma & $\mathrm{S}$ & 114 & PCR-SSP & $\mathrm{Y}$ & $\mathrm{N}$ & $\mathrm{N}$ \\
\hline Baghel et al. 2014" & India & Asian & $\geq 18$ & Post-operative & $\mathrm{S}$ & 239 & PCR & $\mathrm{Y}$ & $\mathrm{N}$ & $\mathrm{N}$ \\
\hline Kothari et al. $2013^{*}$ & India & Asian & NA & Critical ill patient & $\mathrm{S}, \mathrm{SSH}$ & 400 & PCR & $\mathrm{Y}$ & $\mathrm{Y}$ & $\mathrm{N}$ \\
\hline Susantitaphong et al. $2013^{*}$ & USA & Mixed & $\geq 18$ & AKI & $\mathrm{S}$ & 262 & PCR & $\mathrm{Y}$ & $\mathrm{N}$ & $\mathrm{N}$ \\
\hline Azevedo et al. $2012^{*}$ & Brazil & Mixed & $<18$ & PICU patients & S,SS, SSH & 1003 & Taqman & $\mathrm{Y}$ & $\mathrm{N}$ & $\mathrm{Y}$ \\
\hline Song et al. $2012^{*}$ & China & Asian & NA & $\begin{array}{c}\text { Trauma and Critical } \\
\text { ill patient }\end{array}$ & $\mathrm{S}, \mathrm{SS}$ & 1402 & PCR & $\mathrm{Y}$ & $\mathrm{N}$ & $\mathrm{Y}$ \\
\hline Duan et al. $2011^{\circ}$ & China & Asian & $\geq 18$ & Trauma & $\mathrm{S}$ & 305 & PCR-RFLP & $\mathrm{Y}$ & $\mathrm{N}$ & $\mathrm{N}$ \\
\hline Härtel et al. 2011 & Germany & Mixed & Infant & VLBWI & $\mathrm{S}$ & 2870 & PCR & $\mathrm{Y}$ & $\mathrm{N}$ & $\mathrm{N}$ \\
\hline Paskulin et al. 2011" & Brazil & Caucasian & $\geq 18$ & Critical ill patient & $\mathrm{S}, \mathrm{SSH}$ & 520 & PCR-RFLP & $\mathrm{Y}$ & $\mathrm{Y}$ & $\mathrm{Y}$ \\
\hline Carregaro et al. $2010^{*}$ & Brazil & Mixed & $\geq 18$ & ICU patients & $\mathrm{S}, \mathrm{SS}, \mathrm{SSH}$ & 303 & Taqman & $\mathrm{Y}$ & $\mathrm{N}$ & $\mathrm{N}$ \\
\hline Gu et al. $2010^{*}$ & China & Asian & $\geq 18$ & Trauma & $\mathrm{S}$ & 305 & PCR & $\mathrm{Y}$ & $\mathrm{N}$ & $\mathrm{N}$ \\
\hline Menges et al. 2008 & Germany & Caucasian & $\geq 18$ & Trauma & $\mathrm{S}$ & 230 & PCR & $\mathrm{Y}$ & $\mathrm{N}$ & $\mathrm{N}$ \\
\hline Jessen et al. 2007 & Denmark & Caucasian & $\geq 17$ & Gram negative & S,SS, SSH & 304 & PCR & $\mathrm{N}$ & $\mathrm{N}$ & $\mathrm{Y}$ \\
\hline McDaniel et al. 2007 & USA & Mixed & NA & Trauma & $\mathrm{S}$ & 68 & PCR & $\mathrm{Y}$ & $\mathrm{N}$ & $\mathrm{N}$ \\
\hline Garnacho-Montero et al. 2006 & Spain & Caucasian & $>18$ & $\mathrm{ICU}$ & S,SS, SSH & 325 & PCR & $\mathrm{Y}$ & $\mathrm{Y}$ & $\mathrm{Y}$ \\
\hline Schueller et al. 2006 & Germany & Caucasian & $<32$ weeks & Premature infant & $\mathrm{S}$ & 169 & PCR & $\mathrm{Y}$ & $\mathrm{N}$ & $\mathrm{N}$ \\
\hline Sipahi et al. 2006 & Turkey & Caucasian & $<15$ & Critical ill patient & SS & 130 & PCR & $\mathrm{Y}$ & $\mathrm{N}$ & Y \\
\hline Nakada et al. 2005 & Japan & Asian & NA & Critical ill patient & $\mathrm{S}$ & 411 & PCR-RFLP & $\mathrm{Y}$ & $\mathrm{N}$ & $\mathrm{Y}$ \\
\hline Gordon et al. 2004 & UK and Australia & Caucasian & $\geq 18$ & ICU patient & SS, SSH & 566 & $\begin{array}{l}\text { PCR-RFLP, } \\
\text { PCR-SSP }\end{array}$ & $\mathrm{Y}$ & $\mathrm{N}$ & $\mathrm{Y}$ \\
\hline Jaber et al. 2004 & USA & Caucasian & $\geq 18$ & ARF & $\mathrm{S}$ & 61 & PCR-SSP & $\mathrm{Y}$ & $\mathrm{N}$ & $\mathrm{N}$ \\
\hline Balding et al. 2003 & Ireland & Caucasian & $<16$ & Meningococaemia & $\mathrm{S}$ & 572 & PCR & $\mathrm{Y}$ & $\mathrm{N}$ & $\mathrm{Y}$ \\
\hline Calvano et al. 2003 & Spain & Mixed & $>21$ & Post-operative & $\mathrm{S}, \mathrm{SSH}$ & 44 & PCR & $\mathrm{Y}$ & $\mathrm{Y}$ & $\mathrm{Y}$ \\
\hline Schaaf et al. 2003 & Germany & Caucasian & NA & $\begin{array}{l}\text { Pneumococcal } \\
\text { infection }\end{array}$ & $\mathrm{S}, \mathrm{SS}, \mathrm{SSH}$ & 118 & PCR & $\mathrm{Y}$ & $\mathrm{Y}$ & $\mathrm{Y}$ \\
\hline Treszl et al. 2003 & Hungary & Caucasian & Infant & LBWI & $\mathrm{S}$ & 103 & PCR-RFLP & $\mathrm{Y}$ & $\mathrm{N}$ & $\mathrm{N}$ \\
\hline Zhang et al. 2003 & China & Asian & NA & ASP & SSH & 148 & PCR & $\mathrm{Y}$ & $\mathrm{Y}$ & $\mathrm{N}$ \\
\hline Zhang et al. 2003 & China & Asian & NA & $\mathrm{ABP}$ & $\mathrm{SSH}$ & 120 & PCR & $\mathrm{Y}$ & $\mathrm{Y}$ & $\mathrm{N}$ \\
\hline Majetschak et al. 2002 & Netherlands & Caucasian & $\geq 18$ & Trauma & SS & 70 & PCR & $\mathrm{Y}$ & $\mathrm{N}$ & $\mathrm{N}$ \\
\hline Appoloni et al. 2001 & Belgium & Caucasian & NA & ICU patient & $\mathrm{SSH}$ & 34 & PCR & $\mathrm{N}$ & $\mathrm{N}$ & $\mathrm{Y}$ \\
\hline Waterer et al. 2001 & Australia & Mixed & NA & CAP & $\mathrm{S}$ & 280 & PCR & $\mathrm{Y}$ & $\mathrm{N}$ & $\mathrm{Y}$ \\
\hline Mira et al. 1999 & France & Caucasian & NA & ICU patient & $\mathrm{SSH}$ & 176 & PCR & $\mathrm{Y}$ & $\mathrm{Y}$ & $\mathrm{Y}$ \\
\hline Nuntayanuwat et al. 1999 & Thailand & Asian & NA & Meliodosis & $\mathrm{S}$ & 146 & PCR-RFLP & $\mathrm{Y}$ & $\mathrm{N}$ & $\mathrm{N}$ \\
\hline
\end{tabular}

ABP: Acute biliary pancreatitis; AKI: Acute kidney injury; ARF: Acute renal failure; ASP: Acute severe pancreatitis; CAP: Community acquired pneumonia; ICU : Intensive care unit; LBWI: Low birth weight infant; NA: Not available; PCR: Polymerase Chain Reaction; PCR-RFLP: Polymerase chain reaction-restriction fragment length polymorphism; PCR-SSP: Polymerase chain reaction -sequencespecific amplification; PICU: Pediatric intensive care unit; S: Sepsis; SS: Severe sepsis; SSH: Septic shock; N: No; Y: Yes; VLBWI: Very Low birth weight infant; ": Studies which were newly included in the review when compare with previous meta-analysis.

also possible that, since other cytokines help to mediate sepsis, polymorphism in the TNF- $\alpha$ gene by itself is insufficient to significantly affect risk of sepsis-related death. Whether sepsis ultimately leads to mortality can also depend on numerous clinical factors, which cannot be predicted from genetics [51]. Our meta-analysis suggests that future research on risk factors of sepsis-related mortality may wish to focus on other SNPs in the TNF- $\alpha$ gene or on SNPs in other cytokine genes.

Our meta-analysis has several limitations. First, although we added several new studies relative the most recent meta-analysis from 2010 [10], the numbers of studies and subjects in our work were still limited. This may reduce the statistical power for identifying possible associations between TNF- $\alpha-308 \mathrm{~A} / \mathrm{G}$ polymorphism and sepsis, especially septic shock, for which the metaanalysis included only 8 studies. Second, our metaanalysis included only studies in Asians, Caucasians, and populations of mixed or unknown ethnicity. Future work should examine this polymorphism in other populations, such as Hispanics, Africans, and Native Americans. Third, we reviewed only English-language publications. It is 
Table 2: Summary of statistical results

\begin{tabular}{|c|c|c|c|c|c|c|c|}
\hline Statistical model & Group & $\begin{array}{l}\text { Number of } \\
\text { studies }\end{array}$ & $Q$ test $P$ value & $\mathbf{I}^{2}$ & Model & OR (95\% CI) & $P$ value \\
\hline \multirow[t]{7}{*}{$\mathrm{AA}+\mathrm{GA}$ vs. GG } & Overall Sepsis & 33 & $P<0.00001$ & $73 \%$ & Random Model & $1.35[1.10,1.67]$ & 0.005 \\
\hline & Studies with HWE & 23 & $P<0.00001$ & $78 \%$ & Random Model & $1.28[0.99,1.64]$ & 0.06 \\
\hline & Ethnicity & & & & & & \\
\hline & Caucasian & 14 & $P=0.003$ & $58 \%$ & Random Model & $1.50[1.13,2.00]$ & 0.006 \\
\hline & Asian & 11 & $P<0.00001$ & $83 \%$ & Random Model & $1.56[0.97,2.51]$ & 0.07 \\
\hline & Septic shock & 8 & $P=0.17$ & $32 \%$ & Fixed Model & $1.52[1.18,1.95]$ & 0.001 \\
\hline & Mortality & 16 & $P=0.03$ & $45 \%$ & Random Model & $0.99[0.71,1.40]$ & 0.97 \\
\hline \multirow[t]{7}{*}{ AA vs. GA+GG } & Overall Sepsis & 25 & $P=0.002$ & $54 \%$ & Random Model & $1.14[0.74,1.74]$ & 0.55 \\
\hline & Studies with HWE & 21 & $P=0.006$ & $53 \%$ & Random Model & $1.09[0.67,1.75]$ & 0.74 \\
\hline & Ethnicity & & & & & & \\
\hline & Caucasian & 9 & $P=0.58$ & $0 \%$ & Fixed Model & $1.01[0.61,1.66]$ & 0.97 \\
\hline & Asian & 9 & $P<0.0001$ & $78 \%$ & Random Model & $1.57[0.55,4.49]$ & 0.40 \\
\hline & Septic shock & 4 & $P=0.55$ & $0 \%$ & Fixed Model & $2.78[1.20,6.40]$ & 0.02 \\
\hline & Mortality & 12 & $P=0.49$ & $0 \%$ & Fixed Model & $1.75[0.97,3.18]$ & 0.06 \\
\hline \multirow[t]{7}{*}{ AA vs GG } & Overall Sepsis & 25 & $P<0.0001$ & $66 \%$ & Random Model & $1.13[0.68,1.86]$ & 0.64 \\
\hline & Studies with HWE & 21 & $P<0.0001$ & $67 \%$ & Random Model & $1.07[0.60,1.91]$ & 0.81 \\
\hline & Ethnicity & & & & & & \\
\hline & Caucasian & 9 & $P=0.56$ & $0 \%$ & Fixed Model & $1.06[0.64,1.74]$ & 0.83 \\
\hline & Asian & 9 & $P<0.00001$ & $85 \%$ & Random Model & $1.56[0.42,5.75]$ & 0.51 \\
\hline & Septic shock & 4 & $P=0.55$ & $0 \%$ & Fixed Model & $2.84[1.22,6.59]$ & 0.02 \\
\hline & Mortality & 12 & $P=0.50$ & $0 \%$ & Fixed Model & $1.60[0.88,2.92]$ & 0.12 \\
\hline \multirow[t]{7}{*}{ A vs $\mathrm{G}$} & Overall Sepsis & 27 & $P<0.00001$ & $77 \%$ & Random Model & $1.17[0.96,1.42]$ & 0.12 \\
\hline & Studies with HWE & 21 & $P<0.00001$ & $79 \%$ & Random Model & $1.13[0.90,1.41]$ & 0.30 \\
\hline & Ethnicity & & & & & & \\
\hline & Caucasian & 9 & $P=0.59$ & $0 \%$ & Fixed Model & $1.13[0.96,1.32]$ & 0.13 \\
\hline & Asian & 11 & $P<0.00001$ & $87 \%$ & Random Model & $1.46[0.91,2.32]$ & 0.12 \\
\hline & Septic shock & 4 & $P=0.66$ & $0 \%$ & Fixed Model & $1.30[0.97,1.75]$ & 0.08 \\
\hline & Mortality & 12 & $P=0.18$ & $27 \%$ & Fixed Model & $0.91[0.72,1.15]$ & 0.42 \\
\hline
\end{tabular}

possible that our results would have been different if we had searched for literature in other languages. Fourth, we looked at only one SNP in only one sepsis-related gene. The available evidence, including results from the present meta-analysis, highlight the importance of taking into account the potential contributions of other cytokines and signaling pathways in sepsis risk.

Indeed, sepsis is a complicated clinical syndrome arising through interactions between genotype and environment [52]. Future studies should aim to avoid false associations resulting from ethnic differences in genotype frequencies and disease prevalence. Studies should also pursue high methodological quality, and genotype distributions in the controls should be confirmed to satisfy HWE. Functional studies that take into account genetic and environmental factors should investigate how the TNF- $\alpha-308 \mathrm{~A} / \mathrm{G}$ polymorphism affects TNF- $\alpha$ production and the cytokine's role in pathogenesis of sepsis. The results of this work may help improve risk assessment and precision treatment of patients with sepsis.

\section{MATERIALS AND METHODS}

This meta-analysis was performed according to the guidelines of the Preferred Reporting Items for Systematic Reviews according to standard methods recommended for genetic meta-analysis [53-54]. Institutional review board approval was waived since this was a secondary data analysis.

\section{Literature search}

Two authors (HW and SG) independently searched PubMed, EMBASE, Scopus, and Web of Science 
databases up to December 2016 in order to identify studies testing the association between the TNF- $\alpha-308$ $\mathrm{A} / \mathrm{G}$ polymorphism and sepsis risk. The following search terms were used: "Sepsis or severe sepsis or septic shock or septicemia or infection-related systemic inflammatory response syndrome" and "tumor necrosis factor- $\alpha$ or tumor necrosis factor-alpha or TNF- $\alpha$ " and "polymorphism or variant or mutation". The reference lists of identified original studies and review articles were manually reviewed to find additional relevant publications.

\section{Study selection}

Studies were included in the review if they (1) evaluated the association of the TNF- $\alpha-308 \mathrm{~A} / \mathrm{G}$ polymorphism with risk of sepsis or septic shock or risk of sepsis-related mortality, (2) had a case-control design, (3) reported genotype distributions for case and control groups in a way that allowed estimation of odds ratios (ORs) and 95\% confidence intervals (CIs), and (4) were published in English. When duplicate publications involved the same or overlapping data sets, only the study with the larger number of participants was included. If one article contained training and validation groups, each was treated as a separate study.

Abstracts and reviews were excluded from consideration, as were studies that failed to report genotype frequencies. Studies that included patients with sepsis caused by non-bacterial infection were excluded.

\section{Data extraction}

Two authors (HW and SG) independently extracted data from the final set of included studies using a predesigned table. The following data were collected: name of first author, year of publication, country of origin, ethnicity of subjects, source of subjects, sample size, sepsis type, genotyping method, and genotype frequencies in case and

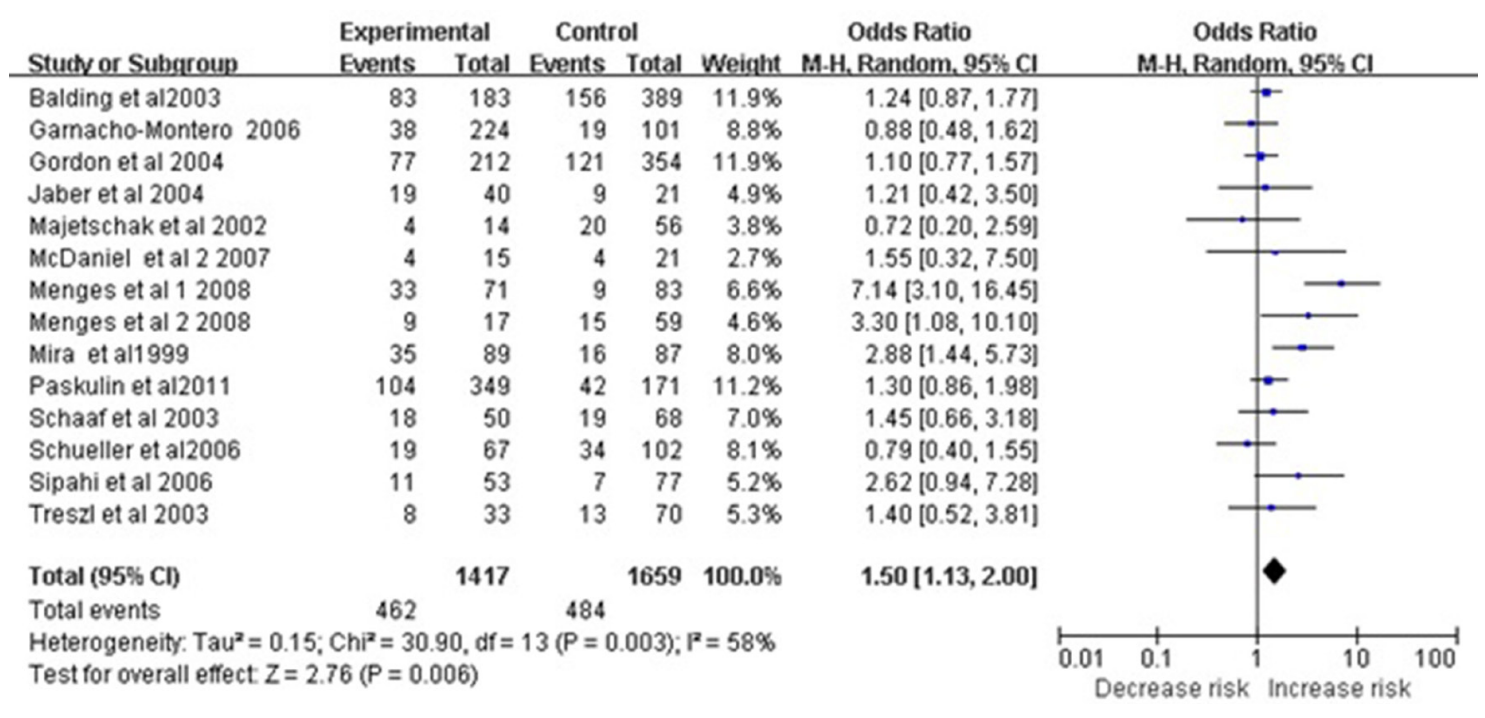

Figure 2: Meta-analysis to evaluate the association between the TNF- $\alpha-308 \mathrm{~A} / \mathrm{G}$ polymorphism and sepsis risk in Caucasian (AA+GA vs. GG). The size of the square is proportional to the weight of each study; horizontal lines represent the $95 \%$ CI.

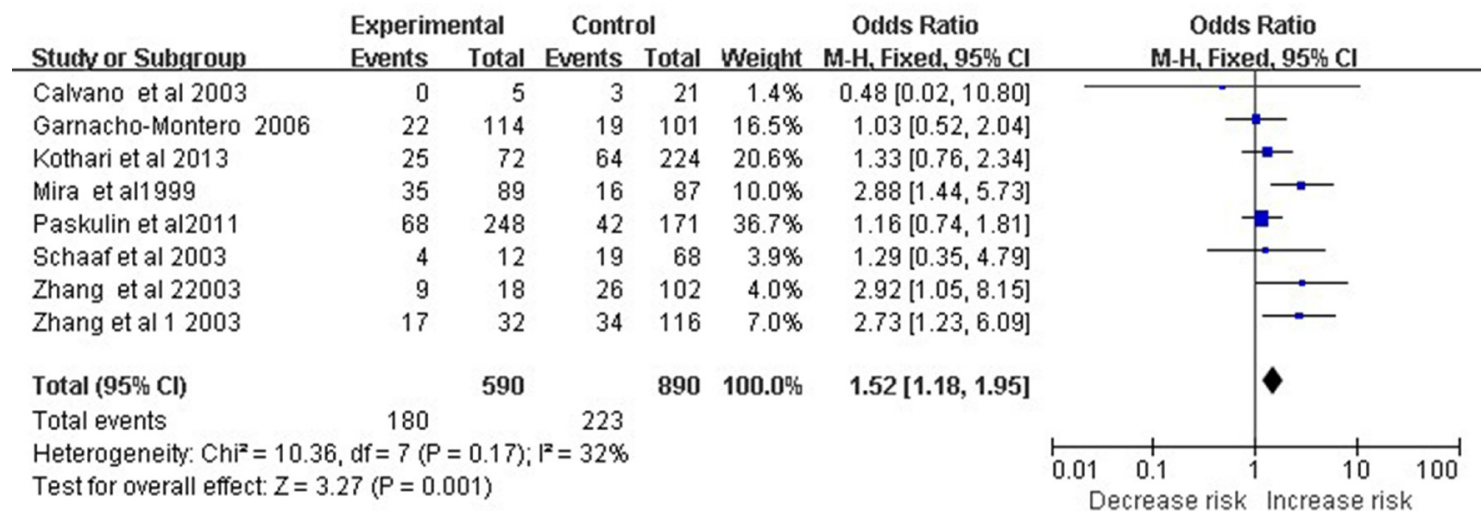

Figure 3: Meta-analysis to evaluate the association between the TNF- $\alpha-308 \mathrm{~A} / \mathrm{G}$ polymorphism and septic shock risk (AA+GA vs. GG). The size of the square is proportional to the weight of each study; horizontal lines represent the $95 \%$ CI. 
control groups. Any disagreement was resolved through discussion with the third author $(\mathrm{CW})$.

\section{Assessment of study quality}

The following questions were assessed for each study: (1) whether the genotype distribution in control groups was consistent with HWE; (2) whether the study listed primer sequences; (3) whether data analysts were blind to genotype and clinical status; and (4) whether a specific definition of sepsis was reported.

\section{Statistical analysis}

Strength of the associations of the TNF- $\alpha-308$ A/G polymorphism with risk of sepsis, septic shock and sepsisrelated mortality was assessed using ORs and 95\% CIs. Significance of the pooled OR was evaluated using the

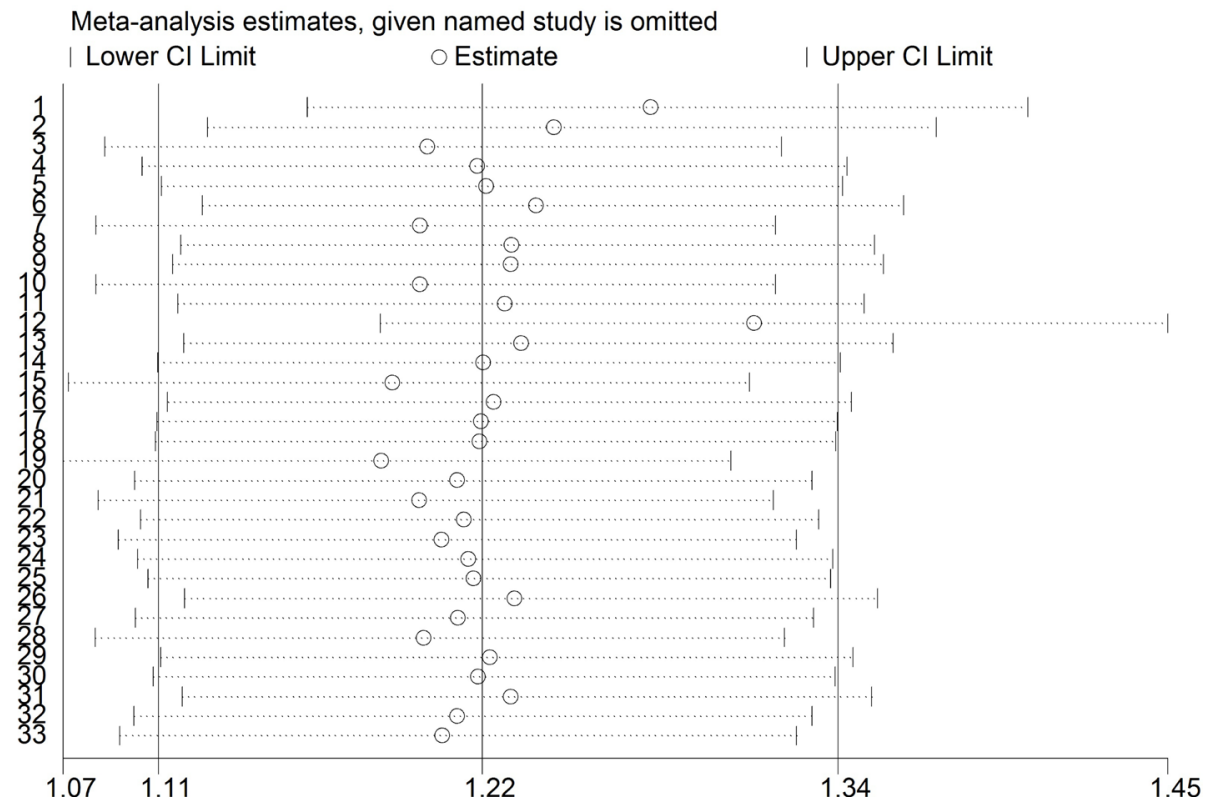

Figure 4: Sensitivity analysis of included studies examining the TNF-a promoter $-308 \mathrm{~A} / \mathrm{G}$ polymorphism and sepsis risk (CC vs. CG + GG).

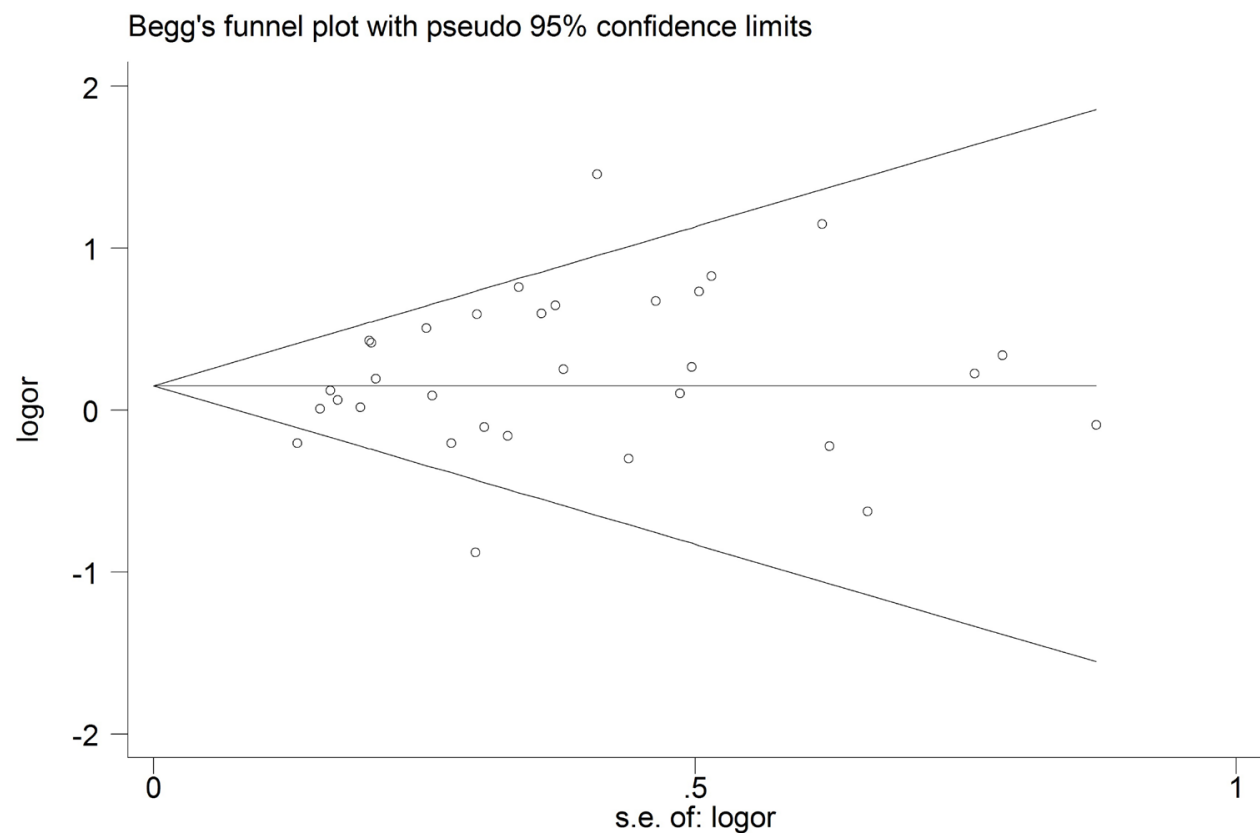

Figure 5: Begg's funnel plot to detect publication bias in studies examining the TNF-a promoter $-308 \mathrm{~A} / \mathrm{G}$ polymorphism and sepsis risk (CC vs. CG + GG). 
Z-test, with $P<0.05$ defined as the significance threshold. Results were calculated according to four genetic models: dominant, $\mathrm{AA}+\mathrm{AG}$ vs. GG; recessive, AA vs. AG+GG; additive, AA vs. GG; and allelic contrast, A vs. G. Subgroup analyses based on ethnicity were also performed.

Heterogeneity was evaluated using the $\chi^{2}$-based $Q$ statistic as well as the $\mathrm{I}^{2}$ statistic, with $P<0.10$ defined as the significance threshold. If $P \geq 0.10$, then data were meta-analyzed using a fixed-effects model; otherwise, a random-effects model was used. Publication bias was assessed using Begg's funnel plots and Egger's test [5556]. Sensitivity analysis was carried out by sequentially excluding individual studies and re-calculating the ORs. All statistical tests were performed using Revman 5.0 (Cochrane Collaboration, Oxford, UK) and STATA 12.0 (Stata Corp., College Station, TX, USA).

\section{Abbreviations}

TNF- $\alpha$ : tumor necrosis factor- $\alpha$; OR: odds ratio; CI: confidence interval; SNP: single nucleotide polymorphism; HWE: Hardy-Weinberg equilibrium;

\section{Author contributions}

HW, SG-, and CW conceived the article, systematic review, meta-analysis, drafted and revised the manuscript. TY, NZ, YW-, LC and FW- systematic review, drafted and revised the manuscript. YS- Guarantor of the paper, taking responsibility for the integrity of the work as a whole, from inception to published article.

\section{ACKNOWLEDGMENTS}

We thank Raven Riordan from University of Missouri for the review of the language.

\section{CONFLICTS OF INTEREST}

None.

\section{FUNDING}

This work was supported by grants from the National Natural Science Foundation of China (81230001, 81300032), and a Project Grant from the Science and Technology Pillar Program of the Department of Science and Technology of Sichuan Province (2015SZ0151). The funders had no role in study design, data collection and analysis, decision to publish, or preparation of the manuscript.

\section{REFERENCES}

1. Dellinger RP, Levy MM, Rhodes A, Annane D, Gerlach H, Opal SM, Sevransky JE, Sprung CL, Douglas IS,
Jaeschke R, Osborn TM, Nunnally ME, Townsend SR, et al. Surviving Sepsis Campaign Guidelines Committee including the Pediatric Subgrou: Surviving sepsis campaign: international guidelines for management of severe sepsis and septic shock: 2012. Crit Care Med. 2013; 41:580-637.

2. Chung LP, Waterer GW. Genetic predisposition to respiratory infection and sepsis. Crit Rev Clin Lab Sci. 2011; 48:250-268.

3. Kumpf O, Schumann RR. Genetic variation in innate immunity pathways and their potential contribution to the SIRS/CARS debate: evidence from human studies and animal models. J Innate Immun. 2010; 2:381-394.

4. Brenner D, Blaser H, Mak TW. Regulation of tumour necrosis factor signalling: live or let die. Nat Rev Immunol. $2015 ; 15: 362-374$.

5. Barber RC, Aragaki CC, Rivera-Chavez FA, Purdue GF, Hunt JL, Horton JW. TLR4 and TNF-alpha polymorphisms are associated with an increased risk for severe sepsis following burn injury. J Med Genet. 2004; 41:808-813.

6. Barber RC, Chang LY, Arnoldo BD, Purdue GF, Hunt JL, Horton JW, Aragaki CC. Innate immunity SNPs are associated with risk for severe sepsis after burn injury. Clin Med Res. 2006; 4:250-255.

7. Surbatovic M, Grujic K, Cikota B, Jevtic M, Filipovic N, Romic P, Strelic N, Magic Z. Polymorphisms of genes encoding tumor necrosis factor-alpha, interleukin-10, cluster of differentiation-14 and interleukin-1ra in critically ill patients. J Crit Care. 2010; 25:542.e1-8.

8. Phumeetham S, Chat-Uthai N, Manavathongchai M, Viprakasit V. Genetic association study of tumor necrosis factor-alpha with sepsis and septic shock in Thai pediatric patients. J Pediatr. 2012; 88:417-422.

9. Montoya-Ruiz C, Jaimes FA, Rugeles MT, López JÁ, Bedoya G, Velilla P. Variants in LTA, TNF, IL1B and IL10 genes associated with the clinical course of sepsis. Immunol Res. 2016; 64:1168-1178.

10. Teuffel O, Ethier MC, Beyene J, Sung L. Association between tumor necrosis factor-alpha promoter $-308 \mathrm{~A} / \mathrm{G}$ polymorphism and susceptibility to sepsis and sepsis mortality: a systematic review and meta-analysis. Crit Care Med. 2010; 38:276-282.

11. Allam G, Alsulaimani AA, Alzaharani AK, Nasr A. Neonatal infections in Saudi Arabia: Association with cytokine gene polymorphisms. Cent Eur J Immunol. 2015; 40:68-77.

12. Cardoso CP, de Oliveira AJ, Botoni FA, Rezende IC, AlvesFilho JC, Cunha Fde Q, Estanislau Jde A, Magno LA, RiosSantos F. Interleukin-10 rs2227307 and CXCR2 rs1126579 polymorphisms modulate the predisposition to septic shock. Mem Inst Oswaldo Cruz. 2015; 110:453-460.

13. Feng B, Mao ZR, Pang K, Zhang SL, Li L. Association of tumor necrosis factor $\alpha-308 \mathrm{G} / \mathrm{A}$ and interleukin-6 -174G/C gene polymorphism with pneumonia-induced sepsis. J Crit Care. 2015; 30:920-923. 
14. Gupta DL, Nagar PK, Kamal VK, Bhoi S, Rao DN. Clinical relevance of single nucleotide polymorphisms within the 13 cytokine genes in North Indian trauma hemorrhagic shock patients. Scand J Trauma Resusc Emerg Med. 2015; 23:96.

15. Baghel K, Srivastava RN, Chandra A, Goel SK, Agrawal J, Kazmi HR, Raj S. TNF- $\alpha$, IL-6, and IL- 8 cytokines and their association with TNF- $\alpha-308$ G/A polymorphism and postoperative sepsis. J Gastrointest Surg. 2014; 18:14861494.

16. Kothari N, Bogra J, Abbas H, Kohli M, Malik A, Kothari D, Srivastava S, Singh PK. Tumor necrosis factor gene polymorphism results in high TNF level in sepsis and septic shock. Cytokine. 2013; 61:676-681.

17. Susantitaphong $\mathrm{P}$, Perianayagam $\mathrm{MC}$, Tighiouart $\mathrm{H}$, Liangos $\mathrm{O}$, Bonventre JV, Jaber BL. Tumor necrosis factor alpha promoter polymorphism and severity of acute kidney injury. Nephron Clin Pract. 2013; 123:67-73.

18. Azevedo ZM, Moore DB, Lima FC, Cardoso CC, Bougleux R, Matos GI, Luz RA, Xavier-Elsas P, Sampaio EP, GasparElsas MI, Moraes MO. Tumor necrosis factor (TNF) and lymphotoxin-alpha (LTA) single nucleotide polymorphisms: importance in ARDS in septic pediatric critically ill patients. Hum Immunol. 2012; 73:661-667.

19. Song Z, Song Y, Yin J, Shen Y, Yao C, Sun Z, Jiang J, Zhu D, Zhang Y, Shen Q, Gao L, Tong C, Bai C. Genetic variation in the TNF gene is associated with susceptibility to severe sepsis, but not with mortality. PLoS One. 2012; 7:e46113.

20. Duan ZX, Gu W, Zhang LY, Jiang DP, Zhou J, Du DY, Zen L, Chen KH, Liu Q, Jiang JX. Tumor necrosis factor alpha gene polymorphism is associated with the outcome of trauma patients in Chinese Han population. J Trauma. 2011; 70:954-958.

21. Härtel C, Hemmelmann C, Faust K, Gebauer C, Hoehn T, Kribs A, Laux R, Nikischin W, Segerer H, Teig N, von der Wense A, Wieg C, Herting E, et al. German Neonatal Network: Tumor necrosis factor- $\alpha$ promoter -308 G/A polymorphism and susceptibility to sepsis in very-lowbirth-weight infants. Crit Care Med. 2011; 39:1190-1195.

22. Paskulin DD, Fallavena PR, Paludo FJ, Borges TJ, Picanço JB, Dias FS, Alho CS. TNF -308G > a promoter polymorphism (rs1800629) and outcome from critical illness. Braz J Infect Dis. 2011; 15:231-238.

23. Carregaro F, Carta A, Cordeiro JA, Lobo SM, Silva EH, Leopoldino AM. Polymorphisms IL10-819 and TLR-2 are potentially associated with sepsis in Brazilian patients. Mem Inst Oswaldo Cruz. 2010; 105:649-656.

24. Gu W, Zeng L, Zhou J, Jiang DP, Zhang L, Du DY, Hu P, Chen K, Liu Q, Wang ZG, Jiang JX. Clinical relevance of 13 cytokine gene polymorphisms in Chinese major trauma patients. Intensive Care Med. 2010; 36:1261-1265.

25. Menges T, König IR, Hossain H, Little S, Tchatalbachev S, Thierer F, Hackstein H, Franjkovic I, Colaris T, Martens F, Weismüller K, Langefeld T, Stricker J, et al. Sepsis syndrome and death in trauma patients are associated with variation in the gene encoding tumor necrosis factor. Crit Care Med. 2008; 36:1456-1462, e1-6.

26. Jessen KM, Lindboe SB, Petersen AL, Eugen-Olsen J, Benfield T. Common TNF-alpha, IL-1 beta, PAI-1, uPA, CD14 and TLR4 polymorphisms are not associated with disease severity or outcome from Gram negative sepsis. BMC Infect Dis. 2007; 7:108.

27. McDaniel DO, Hamilton J, Brock M, May W, Calcote L, Tee LY, Vick L, Newman DB, Vick K, Harrison S, Timberlake G, Toevs C. Molecular analysis of inflammatory markers in trauma patients at risk of postinjury complications. J Trauma. 2007; 63:147-157; discussion $157-8$.

28. Garnacho-Montero J, Aldabo-Pallas T, Garnacho-Montero C, Cayuela A, Jiménez R, Barroso S, Ortiz-Leyba C. Timing of adequate antibiotic therapy is a greater determinant of outcome than are TNF and IL-10 polymorphisms in patients with sepsis. Crit Care. 2006; 10:R111.

29. Schueller AC, Heep A, Kattner E, Kroll M, Wisbauer M, Sander J, Bartmann P, Stuber F. Prevalence of two tumor necrosis factor gene polymorphisms in premature infants with early onset sepsis. Biol Neonate. 2006; 90:229-232.

30. Sipahi T, Pocan H, Akar N. Effect of various genetic polymorphisms on the incidence and outcome of severe sepsis. Clin Appl Thromb Hemost. 2006; 12:47-54.

31. Nakada TA, Hirasawa H, Oda S, Shiga H, Matsuda K, Nakamura M, Watanabe E, Abe R, Hatano M, Tokuhisa T. Influence of toll-like receptor 4, CD14, tumor necrosis factor, and interleukine-10 gene polymorphisms on clinical outcome in Japanese critically ill patients. J Surg Res. 2005; 129:322-328.

32. Gordon AC, Lagan AL, Aganna E, Cheung L, Peters CJ, McDermott MF, Millo JL, Welsh KI, Holloway P, Hitman GA, Piper RD, Garrard CS, Hinds CJ. TNF and TNFR polymorphisms in severe sepsis and septic shock: a prospective multicentre study. Genes Immun. 2004; 5:631-640.

33. Jaber BL, Rao M, Guo D, Balakrishnan VS, Perianayagam MC, Freeman RB, Pereira BJ. Cytokine gene promoter polymorphisms and mortality in acute renal failure. Cytokine. 2004; 25:212-219.

34. Balding J, Healy CM, Livingstone WJ, White B, MynettJohnson L, Cafferkey M, Smith OP. Genomic polymorphic profiles in an Irish population with meningococcaemia: is it possible to predict severity and outcome of disease? Genes Immun. 2003; 4:533-540.

35. Calvano JE, Um JY, Agnese DM, Hahm SJ, Kumar A, Coyle SM, Calvano SE, Lowry SF. Influence of the TNFalpha and TNF-beta polymorphisms upon infectious risk and outcome in surgical intensive care patients. Surg Infect (Larchmt) 2003; 4:163-169.

36. Schaaf BM, Boehmke F, Esnaashari H, Seitzer U, Kothe H, Maass M, Zabel P, Dalhoff K. Pneumococcal septic 
shock is associated with the interleukin-10-1082 gene promoter polymorphism. Am J Respir Crit Care Med. 2003; 168:476-480.

37. Treszl A, Kocsis I, Szathmári M, Schuler A, Héninger E, Tulassay T, Vásárhelyi B. Genetic Variants of TNF- $\alpha$, IL$1 \beta$, IL-4 Receptor $\alpha$-Chain, IL- 6 and IL-10 Genes Are Not Risk Factors for Sepsis in Low-Birth-Weight Infants. Biol Neonate. 2003; 83:241-245.

38. Zhang D, Li J, Jiang ZW, Yu B, Tang X. Association of two polymorphisms of tumor necrosis factor gene with acute severe pancreatitis. J Surg Res. 2003; 112:138-143.

39. Zhang DL, Li JS, Jiang ZW, Yu BJ, Tang XM, Zheng HM. Association of two polymorphisms of tumor necrosis factor gene with acute biliary pancreatitis. World J Gastroenterol. 2003; 9:824-828.

40. Majetschak M, Obertacke U, Schade FU, Bardenheuer M, Voggenreiter G, Bloemeke B, Heesen M. Tumor necrosis factor gene polymorphisms, leukocyte function, and sepsis susceptibility in blunt trauma patients. Clin Diagn Lab Immunol. 2002; 9:1205-1211.

41. Appoloni O, Dupont E, Vandercruys M, Andriens M, Duchateau J, Vincent JL. Association of tumor necrosis factor-2 allele with plasma tumor necrosis factor-alpha levels and mortality from septic shock. Am J Med. 2001; 110:486-488.

42. Waterer GW, Quasney MW, Cantor RM, Wunderink RG. Septic shock and respiratory failure in community-acquired pneumonia have different TNF polymorphism associations. Am J Respir Crit Care Med. 2001; 163:1599-1604.

43. Mira JP, Cariou A, Grall F, Delclaux C, Losser MR, Heshmati F, Cheval C, Monchi M, Teboul JL, Riché F, Leleu G, Arbibe L, Mignon A, et al. Association of TNF2, a TNF-alpha promoter polymorphism, with septic shock susceptibility and mortality: a multicenter study. JAMA. 1999; 282:561-568.

44. Nuntayanuwat S, Dharakul T, Chaowagul W, Songsivilai $\mathrm{S}$. Polymorphism in the promoter region of tumor necrosis factor-alpha gene is associated with severe meliodosis. Hum Immunol. 1999; 60:979-983.

45. Levy MM, Fink MP, Marshall JC, Abraham E, Angus D, Cook D, Cohen J, Opal SM, Vincent JL, Ramsay G; International Sepsis Definitions Conference: 2001 SCCM/ ESICM/ACCP/ATS/SIS International Sepsis Definitions Conference. Intensive Care Med. 2003; 29:530-538.
46. Bone RC, Balk RA, Cerra FB, Dellinger RP, Fein AM, Knaus WA, Schein RM, Sibbald WJ. Definitions for sepsis and organ failure and guidelines for the use of innovative therapies in sepsis. The ACCP/SCCM Consensus Conference Committee. American College of Chest Physicians/Society of Critical Care Medicine. Chest. 1992; 101:1644-1655.

47. Kroeger KM, Steer JH, Joyce DA, Abraham LJ. Effects of stimulus and cell type on the expression of the -308 tumour necrosis factor promoter polymorphism. Cytokine. 2000; 12:110-9.

48. Beutler B, Grau GE. Tumor necrosis factor in the pathogenesis of infectious diseases. Crit Care Med. 1993; 21:S423-435.

49. Qiu P, Cui X, Barochia A, Li Y, Natanson C, Eichacker PQ. The evolving experience with therapeutic TNF inhibition in sepsis: considering the potential influence of risk of death. Expert Opin Investig Drugs. 2011; 20:1555-1564.

50. Hotchkiss RS, Moldawer LL, Opal SM, Reinhart K, Turnbull IR, Vincent JL. Sepsis and septic shock. Nat Rev Dis Primers. 2016; 2:16045.

51. Sweeney TE, Wong HR. Risk Stratification and Prognosis in Sepsis: What Have We Learned from Microarrays? Clin Chest Med. 2016; 37:209-218.

52. Sutherland AM, Russell JA. Issues with polymorphism analysis in sepsis. Clin Infect Dis. 2005; 41:S396-402.

53. Moher D, Liberati A, Tetzlaff J, Altman DG; PRISMA Group. Preferred reporting items for systematic reviews and meta-analyses: the PRISMA statement. Int J Surg. 2010; 8:336-341.

54. Sagoo GS, Little J, Higgins JP. Systematic reviews of genetic association studies. Human Genome Epidemiology Network. PLoS Med. 2009; 6:e28.

55. Begg CB, Mazumdar M. Operating characteristics of a rank correlation test for publication bias. Biometrics. 1994; 50:1088-1101.

56. Egger M, Davey Smith G, Schneider M, Minder C. Bias in meta-analysis detected by a simple, graphical test. BMJ. $1997 ; 315: 629-634$. 